\title{
LED Intercanopy Lighting in Blackberry During Spring Improves Yield as a Result of Increased Number of Fruiting Laterals and Has a Positive Carryover Effect on Autumn Yield
}

\author{
Anabel Rivas, Kang Liu and Ep Heuvelink* \\ Horticulture and Product Physiology, Wageningen University and Research, Wageningen, Netherlands
}

High market price and low availability of local winter and spring production has stimulated production of blackberries in glasshouses at northern latitudes. For this production, light is the main limiting factor. We investigated the potential of intercanopy lighting (ICL) using light emitting diodes (LEDs) to improve blackberry fruit yield in a crop with a spring and an autumn production cycle. During the spring production cycle three

OPEN ACCESS

Edited by:

Sissel Torre

Norwegian University of Life Sciences,

Norway

Reviewed by:

Brian Farneti,

Fondazione Edmund Mach, Italy

Juan Luis Valenzuela,

University of Almería, Spain

*Correspondence:

Ep Heuvelink

ep.heuvelink@wur.n

Specialty section:

This article was submitted to

Crop and Product Physiology,

a section of the journal

Frontiers in Plant Science

Received: 23 October 2020

Accepted: 22 April 2021

Published: 27 July 2021

Citation:

Rivas A, Liu K and Heuvelink E (2021) LED Intercanopy Lighting in Blackberry During Spring Improves Yield as a Result of Increased Number of Fruiting Laterals and Has a Positive

Carryover Effect on Autumn Yield.

Front. Plant Sci. 12:620642.

doi: 10.3389/fpls.2021.620642 light treatments were applied: only natural light (no ICL), 93 or $185 \mu \mathrm{mol} \mathrm{m} \mathrm{m}^{-2} \mathrm{~s}^{-1} \mathrm{ICL}$ In summer the lateral shoots were cut back and $93 \mu \mathrm{mol} \mathrm{m} \mathrm{m}^{-2} \mathrm{~s}^{-1} \mathrm{ICL}$ was applied to all plants after cutting back, investigating a possible carryover effect of supplemental light in spring on autumn production. Fresh fruit yield in spring increased by 79 and $122 \%$ with 93 and $185 \mu \mathrm{mol} \mathrm{m} \mathrm{m}^{-2} \mathrm{~s}^{-1} \mathrm{ICL}$, respectively, compared to no ICL. This represents 3.6 and $2.8 \%$ increase in harvestable product for every additional $1 \%$ of light. A yield component analysis and leaf photosynthesis measurements were conducted. Maximum photosynthetic capacity $\left(A_{\max }\right)$ for leaves at $185 \mu \mathrm{mol} \mathrm{m} \mathrm{m}^{-2} \mathrm{~s}^{-1} \mathrm{ICL}$ was about $50 \%$ higher, and LAI was $41 \%$ higher compared to no ICL. ICL increased the number of fruiting laterals per cane, and this explained $75 \%$ of the increase in yield. $\mathrm{ICL}$ at $185 \mu \mathrm{mol} \mathrm{m} \mathrm{m}^{-2} \mathrm{~s}^{-1}$ resulted in a higher yield compared to no ICL, primarily as a result of higher total dry matter production. Furthermore, a higher fraction of dry matter partitioned to the fruits (0.59 compared to 0.52) contributed to yield increase, whereas fruit dry matter content and fruit quality (sugar and acid content) was not affected by ICL. Averaged over the three light treatments autumn yield was $47 \%$ lower than spring yield. Autumn yield was $10 \%$ higher for plants at ICL $93 \mu \mathrm{mol} \mathrm{m} \mathrm{m}^{-2} \mathrm{~s}^{-1}$ in spring and $36 \%$ higher for plants at $185 \mu \mathrm{mol} \mathrm{m} \mathrm{m}^{-2} \mathrm{~s}^{-1}$ in spring compared to no ICL in spring. This increased autumn yield was caused by more fruiting laterals (less necrotic buds). It is concluded that management practices in spring can have a carryover effect on the autumn production. This is the first scientific paper on the potential for applying LED ICL in blackberries. Further research should focus on optimal intensity of ICL, positioning of supplementary lighting and economic feasibility.

Keywords: supplemental light, intercanopy lighting, blackberries, light emitting diode, bud break, fruiting laterals, fruit quality, yield component analysis 


\section{INTRODUCTION}

Given the relatively small size of the commercial industry, little work has been done to optimize growth conditions for blackberry (Rubus spp.) in glasshouse environments. High market price and low availability of local winter and spring production (Centre for the Promotion of Imports from Developing Countries, 2016) has stimulated production of blackberries in glasshouses at northern latitudes. As reported for other winter-produced crops in northern latitudes, light is a significant environmental factor limiting growth and yield (Marcelis et al., 2006). Consequently, supplemental lighting with High-Pressure Sodium (HPS) lamps during winter has become quite widespread in order to overcome this challenge (Hemming, 2011). Supplemental lighting has been shown to increase photosynthetic rates (Trouwborst et al., 2010) as well as budbreak, for example in roses (Zieslin and Tsujita, 1990). Light-Emitting Diodes (LEDs) make a more energy efficient supplementary lighting possible compared to HPS (Singh et al., 2015). Besides that, LEDs allow for the optimization of light spectra (Massa et al., 2008) and for placing supplementary light in a crop canopy instead of only above the canopy. Higher yields have been reported in cucumber (Hovi et al., 2004) and sweet pepper (Hovi-Pekkanen et al., 2006) when part of the supplementary light is provided as intercanopy lighting (ICL), compared to toplighting only, with the same total supplementary light intensity. These higher yields are mainly due to improved vertical light distribution, which results in increased actual and maximum photosynthesis rates in the lower canopy leaves (Tewolde et al., 2016; Paponov et al., 2020).

Within a canopy receiving only toplighting the exponential decrease in irradiance from the top to the bottom is coupled with a decrease in the red (R): far-red (FR) ratio because unlike redlight $(630 \mathrm{~nm})$, the transmission of far-red light $(730 \mathrm{~nm})$ through the canopy is quite high (Holmes and Smith, 1977). As has been extensively reported, low red:far-red ratios can cause significant phytochrome-mediated morphological responses (Franklin and Whitelam, 2005) including higher internode elongation, larger leaf expansion, reduced leaf thickness, and reduced branching (Dale and Blom, 2004; Leduc et al., 2014) or reduced budbreak in roses (Mor and Halevy, 1984; Wubs et al., 2014).

Typical glasshouse blackberry production systems make use of dormant, biennial-fruiting cultivars. Unlike tomato or cucumber where the apical meristem is always on top, a blackberry cane has approximately $20-25$ potentially active meristems distributed vertically along the cane. After budbreak, subsequent internode elongation and expansion of leaves on the fruiting laterals occurs horizontally, toward the center of the path between rows until a previously formed terminal flower is expressed (Sønsteby and Heide, 2008). In raspberry (Rubus spp.), a closely related crop, it has been observed that a lower red:far-red ratio results in higher internode elongation, and therefore longer fruiting laterals in the lower part of the canopy (Sønsteby et al., 2013). In raspberry the uppermost laterals on a shoot tend to produce the fewest inflorescences. Inflorescence complexity in the buds increases along the cane from the top to the base of the main cane, due to a higher number of buds along the inflorescence axis in the lower bud positions (Heide and Sønsteby, 2011). The yield of a blackberry cane is a function of the number of buds along the main cane that produce laterals, as well as the productivity of each of these fruiting laterals. This varies with the percentage of buds within the lateral that express flowers, the quantity of flowers expressed per bud position, and fruit size (Sønsteby et al., 2009). In raspberry, it has been suggested that this yield potential is often not realized due to insufficient light (Fernandez and Pritts, 1994). Therefore, the application of supplemental light in the lower sections of the canopy could not only improve photosynthesis of the lower leaves, but also the morphological development of the meristems and the potential productivity of the fruiting laterals.

In cultivation under high tunnels or rain shelters, it is generally only possible to produce one summer blackberry crop. In greenhouse cultivation, however, the climate can be controlled which creates possibilities for not only increased fruit yield but also two cropping cycles in the same year. It is possible to obtain a second crop cycle (harvest in autumn) by cutting back the fruiting laterals in summer after the spring harvest has stopped (Pitsioudis et al., 2009).

To date, no work has been done on the modification of light quality and light quantity in a blackberry canopy through the use of LED ICL. ICL offers an opportunity to improve the production of blackberry in greenhouses during lowlight conditions. Therefore, the objective of this study was to determine the potential of LED ICL for improved blackberry yields, particularly in the lower part of the canopy where production is low. Additionally, this study should improve our understanding of the possible effect higher spring yields as a result of ICL has on autumn yields from the same plants.

Morphological development, growth and yield of blackberry plants under natural light was compared with plants under a low or high intensity of supplemental LED ICL in spring in a greenhouse experiment. After spring harvest, the fruiting laterals were cut back and autumn cycle on the same plants started, with all plants receiving the same amount of ICL. We tested two hypotheses: (1) Blackberry yield per cane in the spring crop will increase under ICL, primarily resulting from a higher number of fruits per lateral, and (2) Applying ICL in spring will improve spring yield at the expense of autumn yield.

\section{MATERIALS AND METHODS}

\section{Facilities and Plant Material}

On 11 November, 2016, blackberry long cane plants [commercially-grown Driscoll's variety, interspecific hybrid Rubus spp.; nursery located in Abingdon, United Kingdom $\left.\left(51^{\circ} \mathrm{N}, 1^{\circ} \mathrm{W}\right)\right]$ were delivered to Breda, Netherlands. Pots $(7 \mathrm{~L}$ filled with $100 \%$ coir) containing five canes with a minimum cane diameter of $5 \mathrm{~mm}$ were selected and placed in cold storage at $2^{\circ} \mathrm{C}$. On 11 January 2017, these pots were delivered to Wageningen, Netherlands $\left(52^{\circ} \mathrm{N}, 5.5^{\circ} \mathrm{E}\right)$, and placed the following day into two adjacent Venlo-type glasshouse compartments $(12 \mathrm{~m} \times 12 \mathrm{~m})$. The canes were pruned to a length of $2.0 \mathrm{~m}$. 
In each compartment seven, $9.5 \mathrm{~m}$ long plant rows were grown spaced $1.9 \mathrm{~m}$ apart, oriented North-South. The distance between pots was $0.38 \mathrm{~m}$. Three adjacent rows were taken as a block. Each block was divided into three plots (three light treatments). Light treatments were allocated according to a latin square and layout was such that buffer rows were kept between the blocks. Each $2.5 \mathrm{~m}$ plot contained six pots with the two outer ones as borders on each end. All rows had four buffer pots on each end of the row.

The plants were grown in the glasshouse for almost 1 year. The first (spring) crop cycle took place from 12 January to 7 July, and after cutting back the fruiting laterals a second (autumn) crop cycle took place from 14 July to 22 December.

\section{Spring Crop Cycle \\ Growing Conditions}

Minimum realized temperature during the diel cycle increased gradually from $7^{\circ} \mathrm{C}$ in February to $12^{\circ} \mathrm{C}$ in June and July, maximum temperature increased from 17 to $30^{\circ} \mathrm{C}$. Liquid $\mathrm{CO}_{2}$ was used to enrich the greenhouse air to $600-800 \mathrm{ppm}$ when vents were closed. During ventilation, greenhouse air was kept at ambient $\mathrm{CO}_{2}$ level.

Solar radiation was recorded every $5 \mathrm{~min}$. based on a Kipp solarimeter placed outside the glasshouse. Three quantum sensors (Li-190R, Li-Cor Inc., Lincoln, NE, United States) were placed inside each glasshouse compartment, $3.50 \mathrm{~m}$ above floor level, near the top of the glasshouse, to measure incoming photosynthetically active radiation (PAR). These sensors were connected to a data logger (Li-1400, Li-Cor Inc., Lincoln, NE, United States). Fraction PAR in solar radiation was assumed to be 0.5 (Jacovides et al., 2004). Greenhouse transmissivity was calculated as the ratio between measured PAR inside the greenhouse and calculated PAR outside.

The fruiting laterals were trellised according to commercial standards. At the onset of flowering, a small hive of bumblebees was introduced in the greenhouse compartments. Two weeks later, the bumblebees were removed and replaced by honey bees. A three stage (vegetative growth, flowering and fruiting) standard blackberry nutrient solution was applied according to commercial standards.

\section{LED Intercanopy Lighting Treatments}

Three light treatments were applied: 0,93 , or $185 \mu \mathrm{mol} \mathrm{m}^{-2} \mathrm{~s}^{-1}$ ICL. ICL was applied with two $\left(93 \mu \mathrm{mol} \mathrm{m} \mathrm{m}^{-2} \mathrm{~s}^{-1}\right)$ or four $\left(185 \mu \mathrm{mol} \mathrm{m}^{-2} \mathrm{~s}^{-1}\right)$ interlighting LED modules, each $2.5 \mathrm{~m}$ long and providing 95\% red and 5\% blue light (Philips, Greenpower Production Interlighting Module, 107W, $220 \mu \mathrm{mol} \mathrm{s}^{-1}$ PPF, Eindhoven, Netherlands). The total light output of the LED modules has been measured by Philips own certified lab according to IES LM-79-08; CIE S 025/E:2015; prEN130324:2013.2 standards. Light intensity at plant level was calculated based on this lamp output and the number of modules per $\mathrm{m}^{2}$ ground area. The ICL modules were placed parallel to the row, in the middle of the walkway, $0.95 \mathrm{~m}$ from the center trellis. They centered at $1.34 \mathrm{~m}$ height relative to the floor and were each spaced $0.20 \mathrm{~m}$ apart (Figure 1).

Intercanopy lighting started on 10 February $(13 \mathrm{~h}$ supplemental light, lamps turned on $1 \mathrm{~h}$ before sunrise).
From 6 April onward lamps were on only during the natural photoperiod. In order to prevent light pollution between treatments across the blocks, the side of the LED modules facing the buffer rows was covered with aluminum foil. Rectangles of 0.40 by $0.90 \mathrm{~m}$ white plastic were centered on the ends of the LED modules and hung on the ends of every plot perpendicular to the row orientation, to prevent light pollution between treatments within a block. These were removed on 22 March once the fruiting laterals were elongated enough such that this light pollution could no longer occur.

\section{Destructive Crop Measurements}

A total of seven destructive harvests were made over the course of the experiment approximately every 3 weeks from the start of the experiment. The first two destructive harvests were made on two canes randomly selected from the buffer rows (before start of the ICL treatments). The following destructive harvests were made on two canes randomly selected from pots that were not next to each other within the four plant plot, alternating between selected pots across destructive harvest times. Two canes were collected from each treatment in each block $(n=6)$ in all harvests except the last one (11 July) when samples were only collected from one compartment $(n=3)$. When ICL started, cane density was 13.1 canes $\mathrm{m}^{-1}$. From the start of fruit harvest until the end of the first crop cycle 3 canes per pot were kept which resulted in 7.9 canes $\mathrm{m}^{-1}$.

Bud positions on each cane were numbered from 1 upward, starting at the base of the cane. At each bud position, the fruiting lateral length was measured and the number of receptacles (fruit already harvested), ripe fruits, green fruits, open flowers, closed flower buds, aborted flower buds, and expanded and unexpanded $(>1 \mathrm{~cm}$ in length) leaves were counted. A lateral was considered elongated when the length from the base to the apex was more than $3 \mathrm{~cm}$. Leaves, fruiting laterals and fruit were grouped in sets of five bud positions: $1-5,6-10,11-15,16-20$, and $21+$. Measurements including leaf area and dry weight were made in these bud position groups.

All vegetative plant material was dried for $16 \mathrm{~h}$ at $105^{\circ} \mathrm{C}$ in a ventilated oven. Fruit samples were dried at $50^{\circ} \mathrm{C}$ for $48 \mathrm{~h}$ and then at $105^{\circ} \mathrm{C}$ for $16 \mathrm{~h}$. Primocane shoots (vegetative shoots produced from the crown for production in the following year) were removed, dried, and weighed four times during the first crop cycle.

\section{Fresh Fruit Harvest}

Fresh fruit was harvested twice a week from 16 May until 4 July. Only fully ripe, black fruit was selected for harvest. Malformed fruit, defined as fruit with more than $50 \%$ of the drupelets not fully formed, unevenly ripened fruit and overripe fruit/fruit fallen on the floor were all categorized. Then, all fruit was weighed by category. 10 fully ripe black fruits were randomly selected from the fruit harvested from each plot at every harvest and their fresh weight was determined. These fruits were dried and fruit dry matter content was calculated. This dry matter content was multiplied by the total fresh weight harvested to estimate the total dry weight of the harvested fruit. 


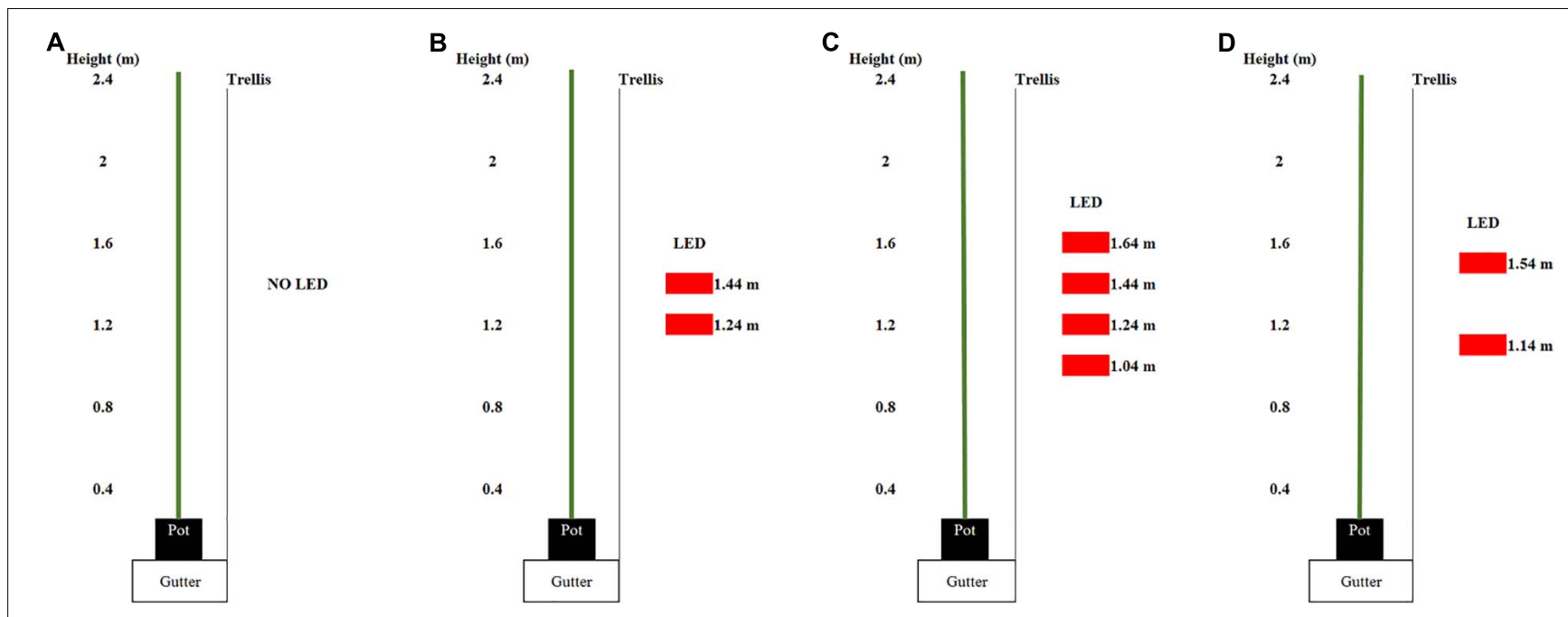

FIGURE 1 | Arrangement of the light emitting diode (LED) modules (displayed as red rectangles) in the spring crop cycle for (A) 0 , (B) 93 , and (C) 185 intercanopy lighting $(\mathrm{ICL})$ and in the autum crop cycle (D). The numbers beside the LED modules show the distance from the LED module to the ground.

\section{Fruit Chemical Analysis}

Three ripe fruits were collected from each plot from the midsection of the canopy between 1.04 and $1.64 \mathrm{~m}$ on three different dates. Fresh berries were frozen in liquid nitrogen and stored at $-20^{\circ} \mathrm{C}$. The berries were freeze dried until stable weight was achieved and then powdered, and then dry weight was taken. For extraction of organic acids and carbohydrates, $5 \mathrm{ml}$ of $75 \%$ ethanol was added to 12 and $18 \mathrm{mg}$ of powder. Samples were vortexed, put in a water bath $\left(80^{\circ} \mathrm{C}, 20 \mathrm{~min}\right)$ and then vortexed again. Samples were then centrifuged $\left(4^{\circ} \mathrm{C}, 8,790 \mathrm{rpm}\right)$ and $1 \mathrm{ml}$ of supernatant was pipetted to another tube where ethanol was evaporated out at $55^{\circ} \mathrm{C} .1 \mathrm{ml}$ deionized water was added, samples were vortexed then put into an ultrasonic bath $(10 \mathrm{~min})$. Afterward they were vortexed again and then placed into a centrifuge $(10 \mathrm{~min})$. Carbohydrate samples were diluted with deionized water at a ratio of 50:1 and organic acid samples at a ratio of 5:1. Carbohydrate samples were analyzed with HPLC (Thermo Scientific Dionex ICS-5000). Organic acids samples were loaded into a different HPLC (Dionex DX-600).

\section{Leaf Photosynthesis}

Photosynthesis light-response curves were determined during the week of 6 March which was during vegetative lateral growth, and during the week of 9 May, which was at the onset of fruit harvest. Measurements were conducted on two representative leaves per plot, only for 0 and $185 \mu \mathrm{mol} \mathrm{m}{ }^{-2} \mathrm{~s}^{-1}$ ICL treatments, and in five randomly selected blocks $(n=5)$.

Measurements were conducted using a Li-6400 portable photosynthesis system (LiCor Inc., Lincoln, NE, United States) equipped with a leaf chamber fluorometer (Li-Cor Part No. 6400-40, area $2 \mathrm{~cm}^{2}$ ). During measurements, $\mathrm{CO}_{2}$ concentration in the leaf chamber was $400 \mathrm{ppm}$, the airflow at $400 \mu \mathrm{mol} \mathrm{s} \mathrm{s}^{-1}$, block temperature at $22^{\circ} \mathrm{C}$ and $\mathrm{RH}$ between 60 and 70\%. The percentage of red light and blue light in the chamber was set at $90 \% / 10 \%$. Average achieved leaf temperature across all light steps was higher in the measurements collected in May $\left(26.7 \pm 0.47^{\circ} \mathrm{C}\right)$ compared to March $\left(21.8 \pm 0.24^{\circ} \mathrm{C}\right)$ due to issues in the regulation of the block temperature.

Leaves were first adapted to $2,000 \mu \mathrm{mol} \mathrm{m} \mathrm{m}^{-2} \mathrm{~s}^{-1}$ for approximately $15 \mathrm{~min}$ until net photosynthetic rate $\left(A_{n}\right)$ and stomatal conductance $\left(g_{s}\right)$ were stable. Then data was logged every $5 \mathrm{~s}$, each light step from $2,000 \mu \mathrm{mol} \mathrm{m} \mathrm{m}^{-2} \mathrm{~s}^{-1}$ down to $1,500,1,000,800,600,400,200,150,100,50,30$, and finally $0 \mu \mathrm{mol} \mathrm{m}{ }^{-2} \mathrm{~s}^{-1}$ was held for a minimum of $30 \mathrm{~s}$ or until $A_{n}$ and $g_{s}$ were stable (Kaiser et al., 2017).

Measured $A_{n}$ values were averaged over the last $30 \mathrm{~s}$ to give one value per light step per leaf. The data for $A_{n}$ response to absorbed irradiance (assuming 0.85 absorbance of incident light) was then fitted using Equation 1 (Ögren and Evans, 1993).

$A_{n}=\frac{\varphi * I+A_{\max }-\left[\left(\varphi * I+A_{\max }\right)^{2}-4 * \theta * \varphi * I * A_{\max }\right]^{0.5}}{2 * \theta}$

Where $\varphi$ is the maximal quantum yield, $I$ is the absorbed irradiance, $A_{n}$ is the leaf photosynthetic rate ( $\mu$ mol $\mathrm{CO}_{2}$ $\left.\mathrm{m}^{-2} \mathrm{~s}^{-1}\right), A_{\max }$ is the light-saturated leaf photosynthetic rate and $\theta$ is the convexity.

\section{Autumn Crop Cycle} Growing Conditions

On 20 and 21 July, all fruiting laterals from the first crop were cut back to one node below the last fruiting node. On this date, the cane density was 7.9 canes $\mathrm{m}^{-1}$ in one experimental compartment and 5.3 canes $\mathrm{m}^{-1}$ in the other compartment. This difference occurred from the week of 11 July onward, since a final destructive harvest concluding the spring cycle was taken from one of the compartments only $(n=3)$. On 24 July a destructive harvest was conducted in the other compartment $(n=3)$ such that the cane density during autumn production cycle was 
5.3 canes $\mathrm{m}^{-1}$ in both compartments. Average greenhouse air temperature gradually decreased from $20^{\circ} \mathrm{C}$ in July and August to $15^{\circ} \mathrm{C}$ in November and December. Liquid $\mathrm{CO}_{2}$ was used to enrich the greenhouse air to 600-800 ppm when vents were closed. During ventilation, greenhouse air was kept at ambient $\mathrm{CO}_{2}$ level.

\section{Light Emitting Diode Interlighting Treatments}

After the spring cropping cycle, LED modules were rearranged such that all plots had two modules and received $93 \mu \mathrm{mol} \mathrm{m} \mathrm{m}^{-2} \mathrm{~s}^{-1}$. In this way supplementary LED light could also be used in the autumn cycle and a possible carry-over effect of spring lighting on autumn production could be studied without the need for more LED modules compared to spring. Modules were placed at a height of 1.14 and $1.54 \mathrm{~m}$ (Figure 1). Supplemental lighting (6 a.m. till 8 p.m.; 14 h) started on 28 July.

\section{Fresh Fruit Harvest and Destructive Crop Measurements}

Fresh fruit was harvested two times per week starting on 3 October until 12 December using the same protocol as for the spring crop. Vegetative laterals that emerged after the July lateral prune were removed once a week. Laterals were considered vegetative if longer than $0.40 \mathrm{~m}$ and only having leaves with five leaflets. The laterals were classified by their point of origin within the vertical canopy: $0.0-1.0 \mathrm{~m}$ from the floor, $1.0-1.8 \mathrm{~m}$ and above $1.8 \mathrm{~m}$. All material was dried and weighed according to the spring protocol.

Two destructive harvests were conducted. The first one was on 24 July, only in the compartment with 7.9 canes $\mathrm{m}^{-1}$. Two canes were randomly selected from two pots in each plot $(n=3)$. The second destructive harvest took place at the end of the experiment on 15 Dec. Two canes were selected from each plot in each compartment $(n=6)$.

At each destructive harvest, buds along the cane were numbered as before and data were collected in groups of 10 buds $(1-10,11-20$, and 21+). Fruit laterals were categorized as emerging from a primary bud or secondary bud. Secondary buds, axillary buds and scale leaf on each lateral were counted. Additionally, the number of necrotic buds along a fruiting lateral was counted. Buds were considered necrotic when more than $50 \%$ of their area was brown. Leaf area, fruiting lateral length, leaf dry weight, fruiting lateral dry weight and cane dry weight of each bud position group previously mentioned were evaluated. On the last destructive harvest date, the number of scars from vegetative laterals as well as the number of unharvested fruits was also counted and weighed. Vegetative and fruit tissues were then oven dried as for the spring cropping cycle.

\section{Data Analysis}

Measures of technical replicates were averaged first and then entered into SPSS (Version 23, IBM Corp, Armonk, NY, United States) as one value for each experimental unit. Analysis of Variance (ANOVA) was conducted to test $(P=0.05)$ for effects of treatment and bud position (when applicable) using row position $(n=3)$, position across greenhouse $(n=3)$ and compartment $(n=2)$ as blocking factors. An error was made during spring fruit harvest in the peak production period, resulting in a missing value for one block, hence final fruit yield analysis was based on five instead of six repetitions. Normality and homogeneity of variance of the residuals was tested using the ShapiroWilk test and Levene's test, respectively. Mean separation was conducted using Fisher's protected LSD-test at $P=0.05$. Data that violated the assumptions of normality were transformed using a square root or natural logarithm function. Data that did not fit assumptions of normality after transformation were analyzed using a Kruskal-Wallis test followed by a Mann-Whitney test for mean separation $(P=0.05)$.

\section{RESULTS}

\section{Spring Crop Cycle}

Total light sum incident on the crop was 22 or $45 \%$ higher when 93 or $185 \mu \mathrm{mol} \mathrm{m} \mathrm{m}^{-2} \mathrm{~s}^{-1}$ ICL was applied, compared to no ICL (Table 1). In February, with an average daily solar light sum of $5.8 \mathrm{~mol} \mathrm{~m}^{-2}$, supplemental light represented 43 or $60 \%$ of the total incoming light. In June, the average daily solar light sum was much higher at $30.2 \mathrm{~mol} \mathrm{~m}^{-2}$, therefore supplemental LED light represented only 15 and 27\% of the total incoming light for 93 and $185 \mu \mathrm{mol} \mathrm{m} \mathrm{m}^{-2} \mathrm{~s}^{-1}$ ICL, respectively.

Fruit harvest started mid May for all three treatments. The cumulatively harvested fresh fruit yield per cane was 79 and 122\% higher for ICL 93 and $185 \mu \mathrm{mol} \mathrm{m}^{-2} \mathrm{~s}^{-1}$, respectively, compared to no ICL (Table 2) as a result of more fruits harvested per cane (Table 2). Individual fruit weight was only slightly higher (5\%) at $185 \mu \mathrm{mol} \mathrm{m}{ }^{-2} \mathrm{~s}^{-1}$. Fruit dry matter content was not significantly affected by ICL (Table 2).

The number of fruits still on the plant at the end of the spring cropping cycle was higher for both levels of ICL compared to no ICL (Table 3). Vegetative biomass increased with increasing ICL intensity although not statistically significant (Table 3). ICL resulted in a larger fraction of biomass allocated to the fruit (0.59-0.60) compared to no ICL (0.52). For bud positions 11-15, biomass allocation to the fruit was 0.67 for $93 \mu \mathrm{mol}$ $\mathrm{m}^{-2} \mathrm{~s}^{-1}$ ICL and 0.62 for $185 \mu \mathrm{mol} \mathrm{m}{ }^{-2} \mathrm{~s}^{-1}$ ICL compared to 0.43 without ICL.

The proportion of elongated laterals was much lower (0.49) on the canes grown without ICL compared to those with ICL

TABLE 1 | Natural and supplemental total light sum when no intercanopy lighting (ICL) was applied, or with 93 or $185 \mu \mathrm{mol} \mathrm{m} \mathrm{m}^{-2} \mathrm{~s}^{-1} \mathrm{ICL}$, during spring cultivation of blackberries.

\begin{tabular}{|c|c|c|c|}
\hline & \multicolumn{3}{|c|}{$\mathrm{ICL}\left(\mu \mathrm{mol} \mathrm{m} \mathrm{m}^{-2} \mathrm{~s}^{-1}\right)$} \\
\hline & 0 & 93 & 185 \\
\hline Natural light sum $\left(\mathrm{mol} \mathrm{m}^{-2}\right)$ & 3,342 & 3,342 & 3,342 \\
\hline Supplemental light sum $\left(\mathrm{mol} \mathrm{m}^{-2}\right)$ & 0 & 755 & 1501 \\
\hline Total light sum (mol m-2) & 3,342 & 4,097 & 4,843 \\
\hline Light sum increase (\%) & - & 22.3 & 44.9 \\
\hline
\end{tabular}


TABLE 2 | Blackberry fresh fruit harvest for 0, 93, or $185 \mu \mathrm{mol} \mathrm{m} \mathrm{m}^{-2} \mathrm{~s}^{-1} \mathrm{ICL}$.

\begin{tabular}{|c|c|c|c|}
\hline \multirow[t]{2}{*}{ Fruit yield parameter (per cane) } & \multicolumn{3}{|c|}{$\mathrm{ICL}\left(\mu \mathrm{mol} \mathrm{m} \mathrm{m}^{-2} \mathrm{~s}^{-1}\right)$} \\
\hline & 0 & 93 & 185 \\
\hline Marketable fresh fruit weight (g) & $636 a^{3}$ & $1139 b$ & $1416 \mathrm{C}$ \\
\hline Non-marketable fresh fruit weight (g) & $19.2 \mathrm{a}$ & $50.5 \mathrm{~b}$ & $49.7 \mathrm{~b}$ \\
\hline Number of fruits ${ }^{1}$ & $61.5 \mathrm{a}$ & $111 \mathrm{~b}$ & $131 \mathrm{c}$ \\
\hline Fruit weight $\left(\mathrm{g}_{\text {berry }}{ }^{-1}\right.$ ) & $10.1 \mathrm{a}$ & $10.1 \mathrm{a}$ & $10.7 \mathrm{~b}$ \\
\hline Fruit dry matter content (\%) ${ }^{2}$ & $12.0 \mathrm{a}$ & $11.9 \mathrm{a}$ & $12.1 \mathrm{a}$ \\
\hline
\end{tabular}

(0.74 for $93 \mu \mathrm{mol} \mathrm{m}{ }^{-2} \mathrm{~s}^{-1}$ and 0.80 for $185 \mu \mathrm{mol} \mathrm{m} \mathrm{m}^{-2} \mathrm{~s}^{-1}$ ) (Figure 2A). ICL of $93 \mu \mathrm{mol} \mathrm{m}{ }^{-2} \mathrm{~s}^{-1}$ showed a nearly maximum proportion of elongated laterals in bud positions 11-15, which did not change when $185 \mu \mathrm{mol} \mathrm{m} \mathrm{m}^{-2} \mathrm{~s}^{-1}$ ICL was applied (Figure 2B). In bud positions 6-10, $93 \mu \mathrm{mol} \mathrm{m} \mathrm{m}^{-2} \mathrm{~s}^{-1} \mathrm{ICL}$ increased the proportion of elongated laterals by $76 \%$, while $185 \mu \mathrm{mol} \mathrm{m} \mathrm{m}^{-2} \mathrm{~s}^{-1}$ ICL resulted in a $113 \%$ increase compared to no ICL. ICL treatments did not significantly influence total fruit number per fruiting lateral (Supplementary Table 1). The correlation between fruit fresh yield per cane and number of fruiting laterals per cane was 0.867 (Figure 3), which means that $75 \%$ of the variation in yield per cane was explained by the number of fruiting laterals per cane.

TABLE 3 | Blackberry crop parameters for 0, 93, or $185 \mu \mathrm{mol} \mathrm{m}{ }^{-2} \mathrm{~s}^{-1}$ ICL.

\begin{tabular}{|c|c|c|c|}
\hline \multirow[t]{2}{*}{ Crop parameter (per cane) } & \multicolumn{3}{|c|}{$\left.\operatorname{ICL}(\mu \mathrm{mol} \mathrm{m})^{-2} \mathrm{~s}^{-1}\right)$} \\
\hline & 0 & 93 & 185 \\
\hline Total fruit number ${ }^{1,2}$ & $115 a^{4}$ & $185 b$ & $169 \mathrm{~b}$ \\
\hline $\begin{array}{l}\text { Number of unharvested (unripe) } \\
\text { fruits }\end{array}$ & $45 \mathrm{a}$ & $42 \mathrm{a}$ & $28 \mathrm{a}$ \\
\hline $\begin{array}{l}\text { Dry weight of unharvested } \\
\text { fruit }(g)\end{array}$ & $27.1 \mathrm{a}$ & $37.4 \mathrm{a}$ & $24.1 \mathrm{a}$ \\
\hline Increase in cane dry weight (g) & $5.07 \mathrm{a}$ & $3.69 \mathrm{a}$ & $8.89 \mathrm{a}$ \\
\hline Leaf area $\left(\mathrm{m}^{2}\right)$ & $1.32 \mathrm{a}$ & $1.69 \mathrm{ab}$ & $1.86 \mathrm{~b}$ \\
\hline Leaf dry weight (g) & $58.5 \mathrm{a}$ & $72.8 \mathrm{ab}$ & $91.0 \mathrm{~b}$ \\
\hline $\begin{array}{l}\text { Specific leaf area }\left(\mathrm{cm}^{2} \mathrm{~g}^{-1} \text { dry }\right. \\
\text { weight) }\end{array}$ & $230 a b$ & $236 \mathrm{~b}$ & $206 \mathrm{a}$ \\
\hline Fruiting lateral dry weight (g) & $43.1 \mathrm{a}$ & $43.4 \mathrm{a}$ & $49.0 \mathrm{a}$ \\
\hline Total vegetative dry weight (g) & $102 \mathrm{a}$ & $116 \mathrm{a}$ & $140 \mathrm{a}$ \\
\hline $\begin{array}{l}\text { Proportion of biomass } \\
\text { allocation to fruits (at } \\
\text { destructive harvest) }\end{array}$ & $0.52 \mathrm{a}$ & $0.60 \mathrm{~b}$ & $0.59 \mathrm{~b}$ \\
\hline
\end{tabular}

The final destructive analysis of the plant occurred during the week of 11 July.

${ }^{1}$ Square root transformed data used in ANOVA.

${ }^{2}$ Includes total number of receptacles (fruit already harvested) and unharvested fruit remaining on plant.

${ }^{3}$ Estimated by multiplying number of receptacles, fruit and flower by average dry matter content and fruit fresh weight.

${ }^{4}$ Different letters within rows indicate significant difference according to Fisher's protected LSD-test $(P=0.05) ; n=3$.
TABLE 4 | Photosynthesis light-response curve (Eq. 1) parameters for blackberry leaves grown at 0 or $185 \mu \mathrm{mol} \mathrm{m}{ }^{-2} \mathrm{~s}^{-1} \mathrm{LED} \mathrm{ICL}$ : quantum yield $(\varphi ; \mu \mathrm{mol}$ $\left.\mu \mathrm{mol}^{-1}\right)$, convexity $(\theta)$, and maximum assimilation rate $\left(A_{\max } ; \mu \mathrm{mol} \mathrm{CO}_{2}\right.$ $\left.\mathrm{m}^{-2} \mathrm{~s}^{-1}\right)$.

\begin{tabular}{|c|c|c|c|}
\hline \multirow[t]{2}{*}{ Month } & \multirow[t]{2}{*}{ Photosynthetic parameter } & \multicolumn{2}{|c|}{ Intercanopy lighting $\left(\mu \mathrm{mol} \mathrm{m} \mathrm{m}^{-2} \mathrm{~s}^{-1}\right)$} \\
\hline & & 0 & 185 \\
\hline \multicolumn{4}{|l|}{ March } \\
\hline & $\varphi$ & $0.07 \mathrm{a}^{1}$ & $0.06 \mathrm{~b}$ \\
\hline & $\theta$ & $0.54 \mathrm{a}$ & $0.63 \mathrm{a}$ \\
\hline & $A_{\max }$ & 10.5 a & $16.5 \mathrm{~b}$ \\
\hline \multicolumn{4}{|l|}{ May } \\
\hline & $\varphi$ & $0.06 \mathrm{a}$ & $0.06 \mathrm{a}$ \\
\hline & $\theta$ & $0.67 \mathrm{a}$ & $0.75 \mathrm{a}$ \\
\hline & $A_{\max }$ & $11.6 \mathrm{a}$ & $16.4 \mathrm{~b}$ \\
\hline
\end{tabular}

${ }^{1}$ Different letters within rows indicate significant difference according to Fisher's protected LSD-test $(P=0.05) ; n=5$.

In March, the quantum yield, or initial slope of the photosynthesis light-response curve (Figure 4) was higher in leaves of no ICL compared to leaves exposed to $185 \mu \mathrm{mol} \mathrm{m} \mathrm{m}^{-2}$ ICL (Table 4). This difference between treatments had disappeared in May. In March, $A_{\max }$ for $185 \mu \mathrm{mol} \mathrm{m}{ }^{-2} \mathrm{~s}^{-1}$ ICL was a $58 \%$ higher compared to no ICL. This difference was somewhat lower in May (42\%) caused by a higher $A_{\max }$ for no ICL.

Considering fruit fresh yield as the product of total dry matter production and fraction of dry matter partitioned to the fruits divided by the fruit dry matter content revealed (Figure 5) that $185 \mu \mathrm{mol} \mathrm{m} \mathrm{m}^{-2} \mathrm{~s}^{-1}$ ICL resulted in a higher yield compared to no ICL, primarily as a result of higher total dry matter production. Besides more light, a higher LAI and $A_{\max }$ contributed to this higher dry matter. Furthermore, a higher fraction of dry matter partitioned to the fruits contributed to yield increase, whereas fruit dry matter content was not influenced by ICL.

Intercanopy lighting did not influence glucose, fructose, sucrose, malate, citrate, and isocitrate concentrations in the fruit (Table 5).

\section{Autumn Crop Cycle}

Despite receiving identical amounts of light during the autumn crop cycle, yield of plants that received 93 or $185 \mu \mathrm{mol} \mathrm{m}^{-2} \mathrm{~s}^{-1}$ ICL in spring were 11 and $36 \%$ higher compared to no ICL in spring, respectively. Only for $185 \mu \mathrm{mol} \mathrm{m} \mathrm{m}^{-2} \mathrm{~s}^{-1}$ ICL this increase in fresh and dry fruit yield was statistically significant (Table 6). Just like in spring, the higher fruit yield resulted from a larger number of fruit harvested, not from heavier fruit (Table 6). The total number of fruit remaining on the plant when harvest stopped was not significantly affected by spring ICL intensities. Total fruit number per cane was significantly higher for $185 \mu \mathrm{mol} \mathrm{m}^{-2} \mathrm{~s}^{-1}$ ICL applied in spring, compared to no ICL in spring (Table 6). Although not statistically significant, $93 \mu \mathrm{mol} \mathrm{m} \mathrm{m}^{-2} \mathrm{~s}^{-1}$ ICL during spring, resulted in $27 \%$ higher total fruit number. Number of harvested ripe fruit was about $56 \%$ of the total fruit number and the fruit 
A

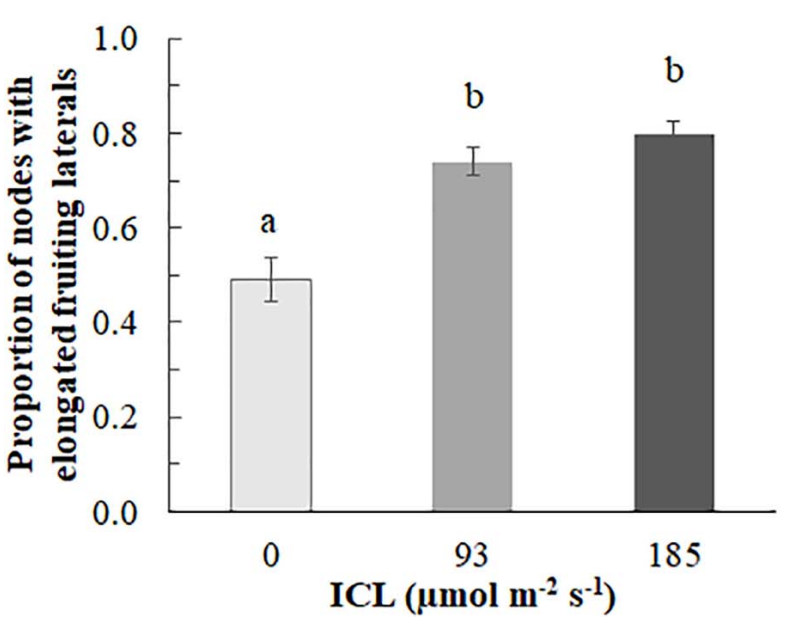

B

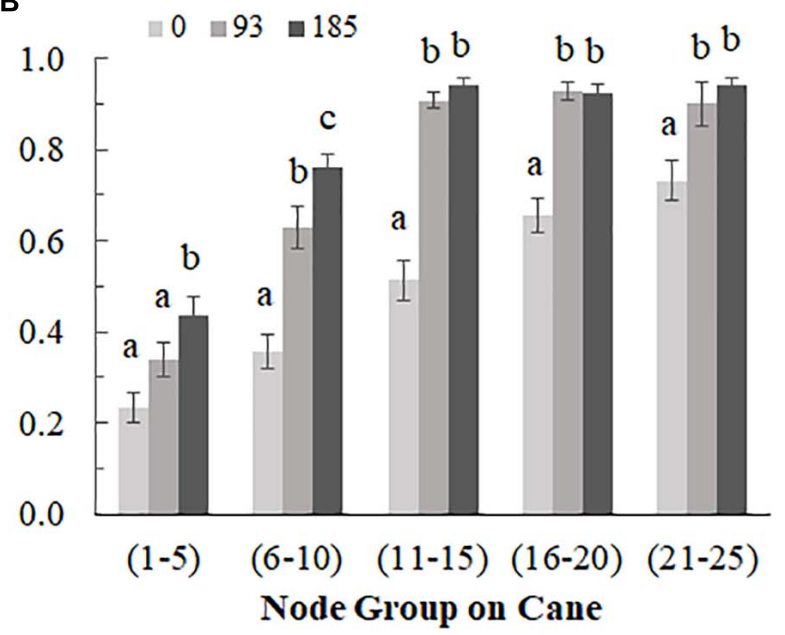

FIGURE 2 | Proportion of buds with elongated fruiting laterals $\left(>3 \mathrm{~cm}\right.$ ) per blackberry cane for 0,93 , or $185 \mu \mathrm{mol} \mathrm{m}^{-2} \mathrm{~s}^{-1}$ ICL (A) on the entire cane and (B) by bud position group (counting from the base of the cane). Data is an average of observations from destructive harvests on 14 March, 4 April, 24 April, and 11 July. (A) Different letters indicate significant differences according to Fisher's protected LSD-test $(P=0.05)$; (B) Different letters within a bud position group, indicate significant differences (Mann-Whitney test, $P=0.05)$. Error bars indicate SEM $(n=6)$.

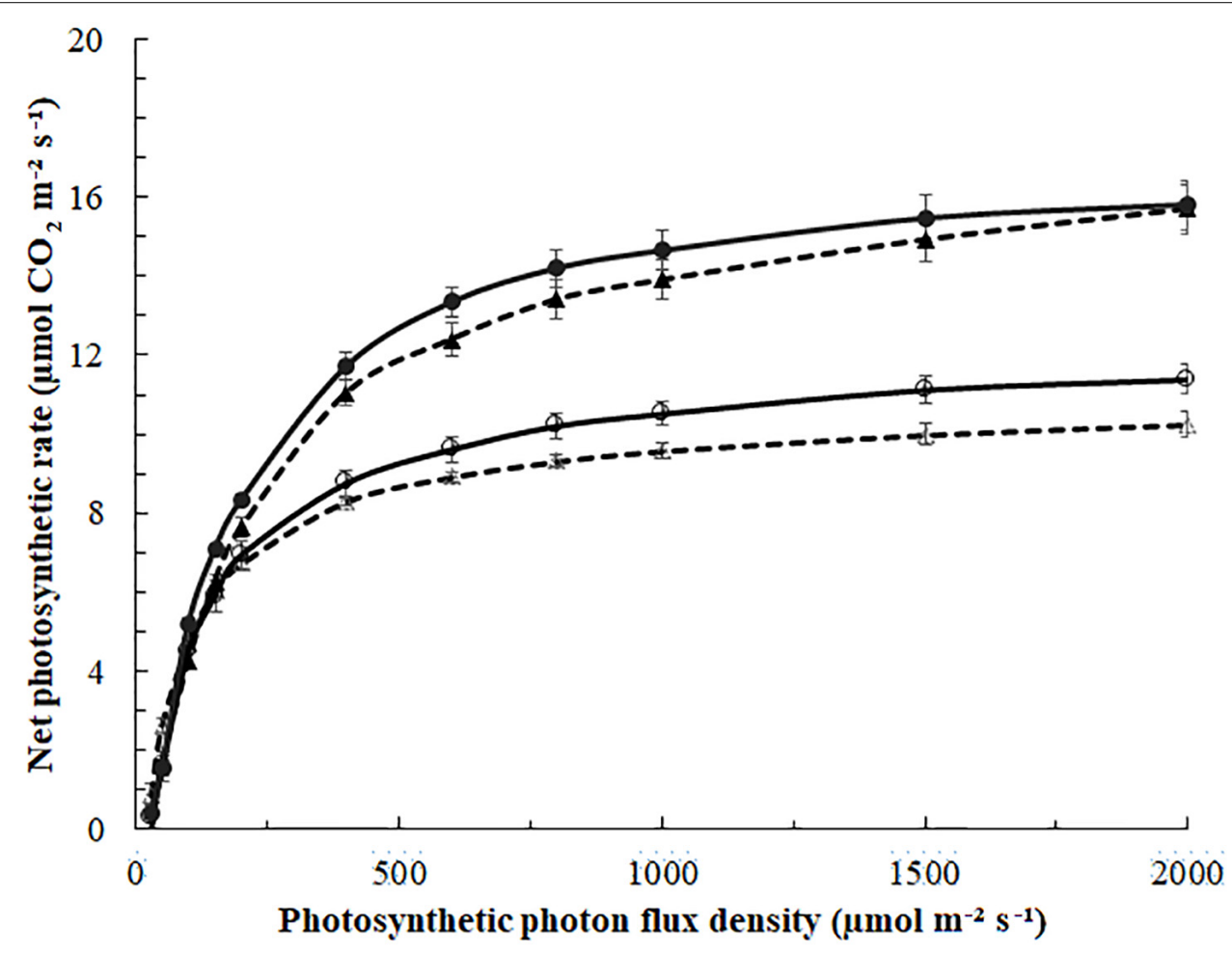

FIGURE 3 | Photosynthesis light-response curves of blackberry leaves exposed to $0(\Delta, \bigcirc)$ or $185(\mathbf{\Lambda}, \bullet) \mu \mathrm{mol} \mathrm{m}^{-2} \mathrm{~s}^{-1} \mathrm{ICL}$ approximately 29 days (March, $\Delta, \mathbf{\Lambda},-$ -) or 89 days (May, $\bigcirc,-$ ) after starting the ICL treatment. Leaf temperature was $22^{\circ} \mathrm{C}$ in March and $27^{\circ} \mathrm{C}$ in May. Curves represent fitted non-rectangular hyperbola (Eq. 1); parameters in Table 4. Error bars indicate SEM $(n=5)$.

number remaining on the plant accounted for about 30\%. Total fruit number was about 3 times higher for bud positions 11 to 20 compared to lower or higher bud position groups
(Supplementary Table 2). Averaged over the 3 ICL treatments autumn yield was $47 \%$ lower than spring yield. No ICL during the spring cycle resulted in the highest amount of necrotic 


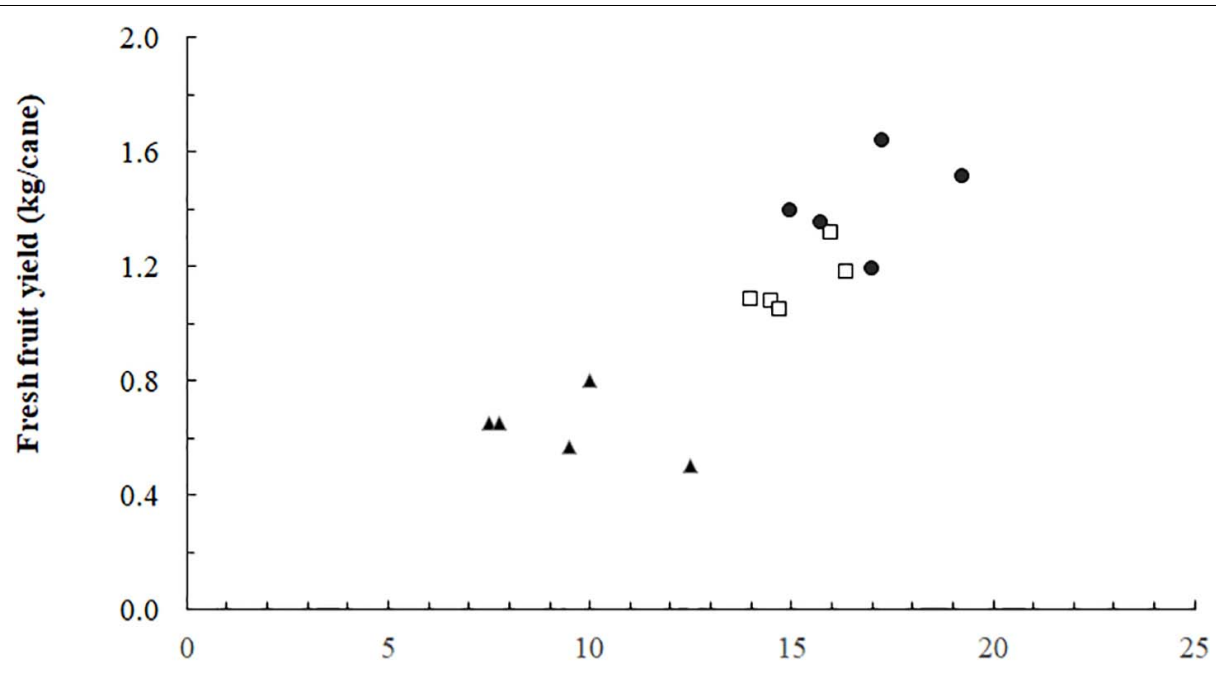

Number of elongated fruiting laterals per cane

FIGURE 4 | Blackberry fresh fruit yield per cane as a function of the number of fruiting laterals per cane (spring crop cycle). Data for 0 ( $\mathbf{\Lambda}$ ), 93 ( $\square$ ), and 185 ( $\mathrm{mol} \mathrm{m} \mathrm{m}^{-2} \mathrm{~s}^{-1} \mathrm{ICL}(n=15$; five replicates for each of the three ICL treatments).

TABLE 5 | Sugar and organic acids content of ripe blackberry fruits grown at 0, 93, or $185 \mu \mathrm{mol} \mathrm{m}{ }^{-2} \mathrm{~s}^{-1} \mathrm{ICL}$.

\begin{tabular}{|c|c|c|c|}
\hline \multirow[t]{2}{*}{ Sugar/acid (g/kg fresh) } & \multicolumn{3}{|c|}{$\mathrm{ICL}\left(\mu \mathrm{mol} \mathrm{m} \mathrm{m}^{-2} \mathrm{~s}^{-1}\right)$} \\
\hline & 0 & 93 & 185 \\
\hline Glucose & $38.5 \mathrm{a}^{1}$ & 39.6 a & $38.4 \mathrm{a}$ \\
\hline Fructose & $37.4 \mathrm{a}$ & $38.5 \mathrm{a}$ & $37.4 \mathrm{a}$ \\
\hline Sucrose & $7.0 \mathrm{a}$ & $6.5 \mathrm{a}$ & $6.9 \mathrm{a}$ \\
\hline Malate & $1.5 \mathrm{a}$ & $1.6 \mathrm{a}$ & $1.7 \mathrm{a}$ \\
\hline Citrate & $0.10 \mathrm{a}$ & $0.10 a$ & $0.10 \mathrm{a}$ \\
\hline Isocitrate & $8.3 \mathrm{a}$ & $7.7 \mathrm{a}$ & $7.2 \mathrm{a}$ \\
\hline
\end{tabular}

${ }^{1}$ Different letters within rows indicate significant difference according to Fisher's protected LSD-test $(P=0.05) ; n=6$.

buds per cane at the start of the autumn production cycle, whereas the total lateral shoot length did not significantly differ (Table 7).

\section{DISCUSSION}

\section{Light Emitting Diode Intercanopy Lighting Increased Number of Fruiting Laterals and Therefore Yield}

Supplementary light has been shown to increase yield in several crops like raspberry (Carew et al., 2003; Sønsteby and Heide, 2008), tomato (Lu et al., 2012), and cucumber (Hao and Papadopoulos, 1999). Intercanopy lighting at 93 or $185 \mu \mathrm{mol} \mathrm{m} \mathrm{m}^{-2} \mathrm{~s}^{-1}$ increased blackberry fresh fruit yield by 79 and 122\%, respectively, compared to no ICL (Table 2). This represents 3.6 and $2.8 \%$ increase in harvestable product for every additional $1 \%$ of light (Table 1). This increase in yield is much larger than the often-cited rule of thumb of $1 \%$ yield increase resulting from $1 \%$ more light (Marcelis et al., 2006). This effect might be somewhat overestimated, as the number of unripe fruit, removed when cutting back for the autumn production cycle, was much higher without ICL (Table 3). At $185 \mu \mathrm{mol} \mathrm{m} \mathrm{m}^{-2} \mathrm{~s}^{-1}$ ICL $17 \%$ of the fruit was left unharvested, whereas without ICL this was $39 \%$. These unripe fruits would have been harvested ripe when spring cycle was continued for a few more weeks. Taking this into account, based on fruit numbers, for $185 \mu \mathrm{mol} \mathrm{m} \mathrm{m}^{-2} \mathrm{~s}^{-1}$ ICL yield would have increased by exactly $1 \%$ for every additional $1 \%$ of light. However, a delay in cutting back would have negatively affected autumn production. Fruit sugar and carbohydrate contents were not significantly affected by ICL (Table 5). Similarly, in tomato increase in yield was reported with LED supplemental lighting while sugar (Lu et al., 2012) and soluble solid (Paponov et al., 2020) content remained unchanged. It is commercially of great importance that such a large yield increase was obtained without negative impact on some key flavor components.

We hypothesized that the number of fruit per lateral would increase when ICL was applied, however, there appeared to be no significant treatment effect on this yield component (Supplementary Table 1). Instead, we observed that the yield component most affected by ICL was the number of elongated fruiting laterals. Approximately $49 \%$ of the laterals elongated when no ICL was applied, whereas this was $74 \%$ for $93 \mu \mathrm{mol}$ $\mathrm{m}^{-2} \mathrm{~s}^{-1}$ ICL and slightly higher for $185 \mu \mathrm{mol} \mathrm{m} \mathrm{m}^{-2} \mathrm{~s}^{-1}$ ICL (Figure 2A). Yield increases in roses in response to supplementary lighting applied in winter have also been attributed to increased bud break (Khosh-Khui and George, 1977). ICL with LEDs ( ${ }^{*} 0 \%$ red and $20 \%$ blue) increased the red:far-red ratio at the middle and low positions in a tomato canopy (Paponov et al., 2020), which is known to stimulate bud 


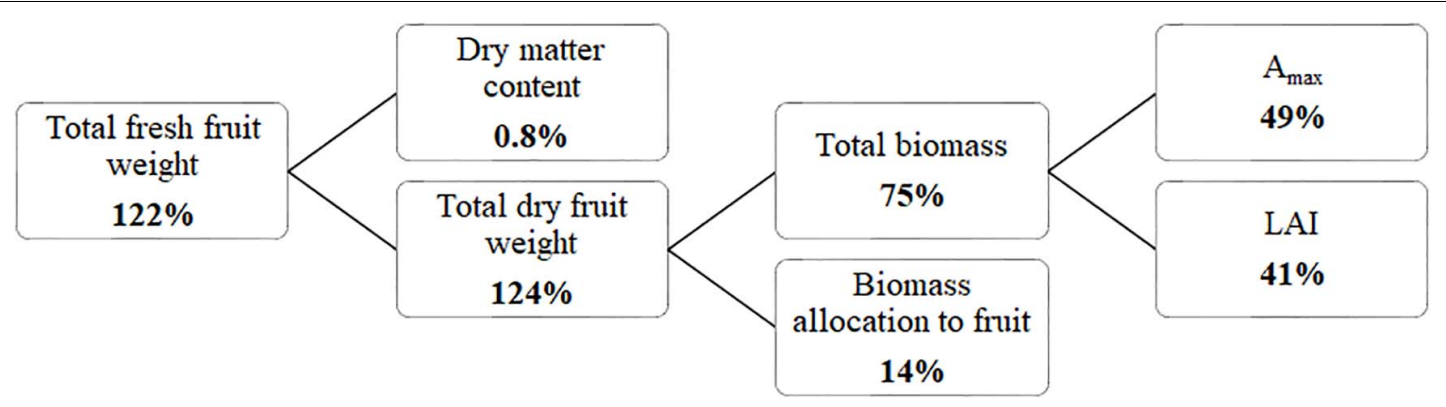

FIGURE 5 | Yield component analysis for a blackberry crop (spring crop cycle). Percentages indicate how much higher the component was for $185 \mu$ mol $\mathrm{m}^{-2} \mathrm{~s}^{-1}$ ICL compared to no ICL. Yield (kg fresh fruit mass $\mathrm{m}^{-2}$ ) $=$ Total dry mass (kg plant dry mass $\mathrm{m}^{-2}$ ) $\times$ Fraction to fruits (fruit dry mass/total dry mass)/fruit dry matter content (fruit dry mass/fruit fresh mass).

TABLE 6 | Blackberry yield per cane during the autumn production cycle (harvest from 3 October till 12 December as affected by spring production cycle ICL treatments.

\begin{tabular}{|c|c|c|c|}
\hline & \multicolumn{3}{|c|}{ ICL intensity $\left(\mu \mathrm{mol} \mathrm{m} \mathrm{m}^{-2} \mathrm{~s}^{-1}\right)$} \\
\hline & 0 & 93 & 185 \\
\hline \multicolumn{4}{|l|}{ Marketable } \\
\hline Fruit fresh weight (g) & $488 a^{1}$ & 540 a & $664 \mathrm{~b}$ \\
\hline Harvested fruit number & $57.9 \mathrm{a}$ & $70.0 \mathrm{~b}$ & $84.6 \mathrm{c}$ \\
\hline Fruit dry weight (g) & $55.1 \mathrm{a}$ & $62.1 \mathrm{a}$ & $76.1 \mathrm{~b}$ \\
\hline \multicolumn{4}{|l|}{ Non-marketable } \\
\hline Fruit fresh weight (g) & $48.9 \mathrm{a}$ & $73.5 \mathrm{~b}$ & $102.7 \mathrm{c}$ \\
\hline Remaining fruit number ${ }^{2}$ & $29.1 \mathrm{a}$ & $38.5 \mathrm{a}$ & $41.7 \mathrm{a}$ \\
\hline
\end{tabular}

${ }^{1}$ Different letters in a row indicate significant differences according to Fisher's protected LSD-test $(P=0.05)$.

${ }^{2}$ The remaining fruit harvest includes unripe fruit and was conducted on Dec 14th.

break (Wubs et al., 2014). Our experiment does not allow to discriminate between the effect of light intensity and light quality on bud break. However, Wubs et al. (2014) concluded that local light intensity, not red:far-red ratio, was the most important factor influencing bud break in rose.

The proportion of elongated laterals in biennial-producing canes of raspberries tends to be higher in the top of the cane due to paradormancy imposed on the basal buds by the apical buds (White et al., 1999). In this experiment, a similar response was observed. Consequently, from bud position 11 and higher,
$93 \mu \mathrm{mol} \mathrm{m}{ }^{-2} \mathrm{~s}^{-1}$ ICL seemed to provide enough light to achieve maximum number of elongated fruiting laterals (Figure $2 \mathbf{B}$ ) as $185 \mu \mathrm{mol} \mathrm{m} \mathrm{m}^{-2} \mathrm{~s}^{-1}$ ICL did not further increase this number. For the basal buds (position 1-10), the fruiting lateral elongation showed a positive correlation with increasing light intensity. In rose, the role of local light on the bud (Girault et al., 2008; Roman et al., 2016), has been shown to function mainly by influencing the ability of the developing shoots to draw assimilates (Mor and Halevy, 1980). The unsaturated response to ICL intensities for the basal buds (position 1-10) suggests further increases in lateral elongation rates could have been achieved by supplying higher light intensities directly on the lower part of the canes.

\section{Biomass Partitioning and Leaf Photosynthesis}

Biomass partitioning to the fruits was higher when ICL was applied (Table 3), which is in accordance with various works reported for other crops (Marcelis, 1993). The largest positive effects of ICL were found in bud positions 11-15, the positions receiving the highest supplemental light intensity and red:far-red ratio (data not shown). Biomass partitioning to the fruit is highly correlated with the number of fruits (Marcelis, 1996) and we observed the greatest increases in fruit number under ICL in the lower part of the canopy. The low SLA at $185 \mu \mathrm{mol} \mathrm{m}^{-2} \mathrm{~s}^{-1} \mathrm{ICL}$ reflects thicker leaves (Table 3) and is a well-known acclimation response to higher light intensity (Evans and Poorter, 2001).

TABLE 7 | Total number of necrotic buds and total lateral length (destructive measurement at start of autumn cycle, 24-28 July). No significant interaction between bud position and spring ICL intensity was found.

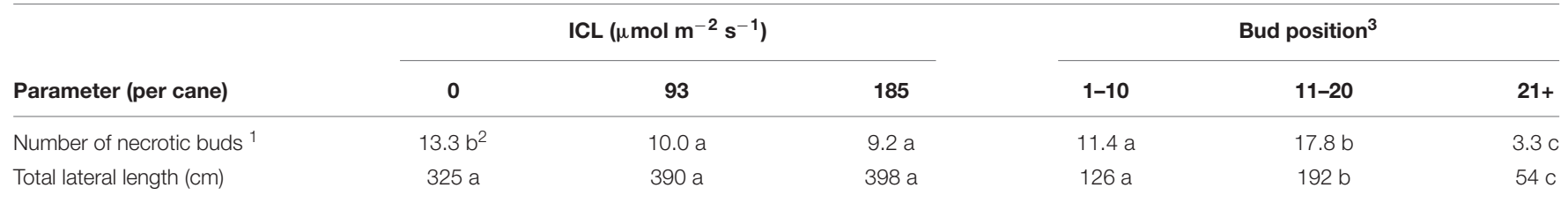

${ }^{1}$ Buds with internal brown colour larger than $50 \%$ of their area were considered necrotic.

2 Means followed by a different letter in a row comparing the 3 ICL intensities, or comparing the 3 bud positions differ significantly according to Fisher's protected LSD-test $(P=0.05), n=3$.

${ }^{3}$ Bud position counted from the base of the cane. 
Under low light conditions, quantum yield and convexity of the photosynthesis light-response curve are the most important parameters for assessing the productivity of a leaf. In March, leaves not exposed to ICL showed a higher quantum yield compared to $185 \mu \mathrm{mol} \mathrm{m}{ }^{-2} \mathrm{~s}^{-1}$ ICL (Table 4), which suggests higher efficiency under low light conditions (Boardman, 1977). In May, this difference had disappeared. In both March and May, leaves exposed to $185 \mu \mathrm{mol} \mathrm{m} \mathrm{m}^{-2} \mathrm{~s}^{-1}$ ICL showed a higher $A_{\max }, 58$ and $42 \%$, respectively, when compared to no ICL. ICL resulting in increased leaf photosynthetic capacity for lower leaves in the canopy was also shown by Dueck et al. (2012) for tomato and Pettersen et al. (2010) for cucumber.

\section{Positive Effect of ICL on Yield in Spring Carries Over to Autumn Production Cycle}

We hypothesized that an increased spring production as a result of spring ICL would come at the expense of autumn production. However, results showed the opposite, ICL in spring increased spring production (Table 2) as well as autumn production (Table 6). The number of secondary laterals from scale buds increased with increased supplementary light intensity in spring (Table 4). This increase is most likely caused by the lower number of necrotic buds. A negative relationship between light intensity and bud necrosis was also found in grapevines. A period of 15 days of shading of individual buds or entire shoots at photosynthetic photon flux density (PPFD) less than 1-2\% of full sunlight was sufficient to significantly raise bud necrosis above that of non-shaded control vines (Perez and Kliewer, 1990).

The much lower yield in the autumn cycle compared to the spring cycle probably results from the lower light levels during the fruit production period in autumn.

This it the first scientific report on the potential for applying LED ICL in greenhouse-grown blackberries. Further research should focus on optimal intensity of ICL and the positioning of supplementary lighting (position of ICL modules in the crop, but also ratio between toplighting and ICL). Furthermore, a yield increase by $79 \%$ in spring production and a positive carryover effect of $11 \%$ yield increase in autumn as a result of $93 \mu \mathrm{mol} \mathrm{m} \mathrm{m}^{-2} \mathrm{~s}^{-1}$ ICL is very promising and certainly warrants investigation in the economic feasibility of ICL in blackberries.

\section{CONCLUSION}

- Applying 93 or $185 \mu \mathrm{mol} \mathrm{m} \mathrm{m}^{-2} \mathrm{~s}^{-1}$ ICL in greenhousegrown blackberry during spring increased spring fresh fruit yields by 79 and $122 \%$, respectively.

\section{REFERENCES}

Boardman, N. K. (1977). Comparative photosynthesis of sun and shade plants. Annu. Rev. Plant Physiol. 28, 355-377. doi: 10.1146/annurev.pp.28.060177. 002035
- Higher yield mainly resulted from higher total dry matter production and to a lesser extend from a higher partitioning to the fruits.

- A larger number of elongated laterals per cane under LED ICL explained $75 \%$ of this yield increase.

- Fruit sugar or acid content was not influenced by LED ICL.

- Autumn yield was $11 \%$ higher for $93 \mu \mathrm{mol} \mathrm{m} \mathrm{m}^{-2} \mathrm{~s}^{-1}$ and $36 \%$ higher for $185 \mu \mathrm{mol} \mathrm{m}{ }^{-2} \mathrm{~s}^{-1}$ spring ICL, despite the fact that in autumn no difference in LED light treatments was implied (same light level).

- This increased autumn yield was caused by more fruiting laterals (less necrotic buds).

\section{DATA AVAILABILITY STATEMENT}

The raw data supporting the conclusions of this article will be made available by the authors, without undue reservation.

\section{AUTHOR CONTRIBUTIONS}

$\mathrm{AR}$ and $\mathrm{EH}$ designed and initiated the experiment. AR conducted the measurements and analysis for the spring cropping cycle and wrote a first draft of the manuscript. KL conducted the measurements and analysis for the autumn cropping cycle. EH supervised the measurements and data analysis and finalized the manuscript. The manuscript has been read and approved by all authors.

\section{FUNDING}

We gratefully acknowledge the financial support by Driscoll's Strawberry Associates, Watsonville, CA, United States.

\section{ACKNOWLEDGMENTS}

We thank Jelle Geurts for conducting the fruit quality analysis as well as the personnel of Unifarm, Wageningen University for excellent crop cultivation. Finally, we would also like to thank the late Fanny Pitsoudis of Driscoll's for his stimulating interest in our work and for providing crop cultivation advice.

\section{SUPPLEMENTARY MATERIAL}

The Supplementary Material for this article can be found online at: https://www.frontiersin.org/articles/10.3389/fpls.2021. 620642/full\#supplementary-material

Carew, J. G., Mahmood, K., Darby, J., Hadley, P., and Battey, N. H. (2003). The effect of temperature, photosynthetic photon flux density, and photoperiod on the vegetative growth and flowering of 'Autumn Bliss' raspberry. J. Am. Soc. Hortic. Sci. 128, 291-296. doi: 10.21273/jashs.128.3. 0291 
Centre for the Promotion of Imports from Developing Countries (2016). Exporting Fresh Berries to Europe. The Hague: Centre for the Promotion of Imports from Developing Countries.

Dale, A., and Blom, T. J. (2004). Far-red light alters primocane morphology of red raspberry. HortScience 39, 973-974. doi: 10.21273/HORTSCI.39.5.973

Dueck, T. A., Janse, J., Eveleens, B. A., Kempkes, F. L. K., and Marcelis, L. F. M. (2012). Growth of tomatoes under hybrid LED and HPS lighting. Acta Hortic. 952, 335-342. doi: 10.17660/actahortic.2012.952.42

Evans, J. R., and Poorter, H. (2001). Photosynthetic acclimation of plants to growth irradiance: the relative importance of specific leaf area and nitrogen partitioning in maximizing carbon gain. Plant Cell Environ. 24, 755-767. doi: 10.1046/j. 1365-3040.2001.00724.x

Fernandez, G. E., and Pritts, M. P. (1994). Growth, carbon acquisition, and source-sink relationships in 'Titan' red raspberry. J. Am. Soc. Hortic. Sci. 119, 1163-1168. doi: 10.21273/jashs.119.6.1163

Franklin, K. A., and Whitelam, G. C. (2005). Phytochromes and shade-avoidance responses in plants. Ann. Bot. 96, 169-175. doi: 10.1093/aob/mci165

Girault, T., Bergougnoux, V., Combes, D., Viemont, J. D., and Leduc, N. (2008). Light controls shoot meristem organogenic activity and leaf primordia growth during bud burst in Rosa sp. Plant Cell Environ. 31, 1534-1544. doi: 10.1111/j. 1365-3040.2008.01856.x

Hao, X., and Papadopoulos, A. P. (1999). Effects of supplemental lighting and cover materials on growth, photosynthesis, biomass partitioning, early yield and quality of greenhouse cucumber. Sci. Hortic. 80, 1-18. doi: 10.1016/s03044238(98)00217-9

Heide, O. M., and Sønsteby, A. (2011). Physiology of flowering and dormancy regulation in annual- and biennial-fruiting red raspberry (Rubus idaeus L.) a review. J. Hortic. Sci. Biotechnol. 86, 433-442. doi: 10.1080/14620316.2011. 11512785

Hemming, S. (2011). "Use of natural and artificial light in horticulture -interaction of plant and technology," in Proceedings of the VI International Symposium on Light in Horticulture, eds E. Goto and S. Hikosaka (Tsukuba: Acta Hort.), 15-19. doi: 10.1016/b978-0-12-813973-8.00003-8

Holmes, M. G., and Smith, H. (1977). The function of phytochrome in the natural environment-II. The influence of vegetation canopies on the spectral energy distribution of natural daylight. Photochem. Photobiol. 25, 539-545. doi: 10. 1111/j.1751-1097.1977.tb09125.x

Hovi, T., Näkkilä, J., and Tahvonen, R. (2004). Interlighting improves production of year-round cucumber. Sci. Hortic. 102, 283-294. doi: 10.1016/j.scienta.2004. 04.003

Hovi-Pekkanen, T., Näkkilä, J., and Tahvonen, R. (2006*). Increasing productivity of sweet pepper with interlighting. Acta Hortic. 711, 165-170. doi: 10.17660/ actahortic.2006.711.19

Jacovides, C. P., Timvios, F. S., Papaioannou, G., Asimakopoulos, D. N., and Theofilou, C. M. (2004). Ratio of PAR to broadband solar radiation measured in Cyprus. Agric. For. Meteorol. 121, 135-140. doi: 10.1016/j.agrformet.2003.10. 001

Kaiser, E., Kromdijk, J., Harbinson, J., Heuvelink, E., and Marcelis, L. F. M. (2017). Photosynthetic induction and its diffusional, carboxylation and electron transport processes as affected by $\mathrm{CO}_{2}$ partial pressure, temperature, air humidity and blue irradiance. Ann. Bot. 119, 191-205. doi: 10.1093/aob/ mcw226

Khosh-Khui, M., and George, R. A. T. (1977). Responses of glasshouse roses to light conditions. Sci. Hortic. 6, 223-235. doi: 10.1016/0304-4238(77)90066-8

Leduc, N., Roman, H., Barbier, F., Péron, T., Huché-Thélier, L., Lothier, J., et al. (2014). Light signaling in bud outgrowth and branching in plants. Plants 3, 223-250. doi: 10.3390/plants3020223

Lu, N., Maruo, T., Johkan, M., Hohjo, M., Tsukagoshi, S., Ito, Y., et al. (2012). Effects of supplemental lighting with Light-Emitting Diodes (LEDs) on tomato yield and quality of single-truss tomato plants grown at high planting density. Environ. Control Biol. 50, 63-74. doi: 10.2525/ecb.50.63

Marcelis, L. F. M. (1993). Fruit growth and biomass allocation to the fruits in cucumber. 2. effect of irradiance. Sci. Hortic. 54, 123-130. doi: 10.1016/03044238(93)90060-4

Marcelis, L. F. M. (1996). Sink strength as a determinant of dry matter partitioning in the whole plant. J.Exp. Bot. 47, 1281-1291. doi: 10.1093/jxb/47.special_issue. 1281

Marcelis, L. F. M., Broekhuijsen, A. G. M., Nijs, E. M. F. M., Raaphorst, M. G. M., and Meinen, E. (2006). Quantification of the growth response to light quantity of greenhouse grown crops. Acta Hortic. 711, 97-104. doi: 10.17660/actahortic. 2006.711.9

Massa, G. D., Kim, H.-H., Wheeler, R. M., and Mitchell, C. A. (2008). Plant productivity in response to LED lighting. HortScience 43, 1951-1956. doi: 10.21273/hortsci.43.7.1951

Mor, Y., and Halevy, A. H. (1980). Promotion of sink activity of developing rose shoots by light. Plant Physiol. 66, 990-995. doi: 10.1104/pp.66.5.990

Mor, Y., and Halevy, A. H. (1984). Dual effect of light on flowering and sprouting of rose shoots. Physiol. Plant. 61, 119-124.

Ögren, E., and Evans, J. R. (1993). Photosynthetic light-response curves. Planta $189,182-190$

Paponov, M., Kechasov, D., Lacek, J., Verheul, M. J., and Paponov, I. A. (2020). Supplemental light-emitting diode inter-lighting increases tomato fruit growth through enhanced photosynthetic light use efficiency and modulated root activity. Front. Plant Sci. 10:1656. doi: 10.3389/fpls.2019.01656

Perez, J., and Kliewer, W. M. (1990). Effect of shading on bud necrosis and bud fruitfulness of Thompson seedless grapevines. Am. J. Enol. Vitic. 41, 168-175.

Pettersen, R. I., Torre, S., and Gislerød, H. R. (2010). Effects of intracanopy lighting on photosynthetic characteristics in cucumber. Sci. Hortic. 125, 77-81.

Pitsioudis, F., Odeurs, W., and Meesters, P. (2009). Early and late production of raspberries, blackberries and red currants. Acta Hortic. 838, 33-37. doi: 10.17660/ActaHortic.2009.838.3

Roman, H., Girault, T., Barbier, F., Péron, T., Brouard, N., Pìnèík, A., et al. (2016). Cytokinins are initial targets of light in the control of bud outgrowth. Plant Physiol. 172, 489-509.

Singh, D., Basu, C., Meinhardt-Wollweber, M., and Roth, B. (2015). LEDs for energy efficient greenhouse lighting. Renewable Sustainable Energy Rev. 49, 139-147.

Sønsteby, A., and Heide, O. M. (2008). Environmental control of growth and flowering of Rubus idaeus L. cv. glen ample. Sci. Hortic. 117, 249-256.

Sønsteby, A., Myrheim, U., Heiberg, N., and Heide, O. M. (2009). Production of high yielding red raspberry long canes in a Northern climate. Sci. Hortic. 121, 289-297.

Sønsteby, A., Stavang, J. A., and Heide, O. M. (2013). Production of high-yielding raspberry long canes: the way to $3 \mathrm{~kg}$ of fruit per cane. J. Hortic. Sci. Biotechnol. $88,591-599$.

Tewolde, F. T., Lu, N., Shiina, K., Maruo, T., Takagaki, M., Kozai, T., et al. (2016). Nighttime supplemental LED inter-lighting improves growth and yield of single-truss tomatoes by enhancing photosynthesis in both winter and summer. Front. Plant Sci. 7:448. doi: 10.3389/fpls.2016.00448

Trouwborst, G., Oosterkamp, J., Hogewoning, S. W., Harbinson, J., and van Ieperen, W. (2010). The responses of light interception, photosynthesis and fruit yield of cucumber to LED-lighting within the canopy. Physiol. Plant. 138, 289-300.

White, J. M., Wainwright, H., and Ireland, C. R. (1999). Endodormancy and paradormancy in the raspberry cultivar 'Glen Clova'. Acta Hortic. 505, 199-205.

Wubs, A. M., Heuvelink, E., Marcelis, L. F. M., Buck-Sorlin, G. H., and Vos, J. (2014). Axillary budbreak in a cut rose crop as influenced by light ntensity and red:far-red ratio at bud level. J. Amer. Soc. Hort. Sci. 139, 131-138.

Zieslin, N., and Tsujita, M. J. (1990). Response of Miniature Roses to Supplementary Illumination. 1. Light Intensity. Amsterdam: Elsevier Science Publishers B.V, $113-121$.

Conflict of Interest: The authors declare that the research was conducted in the absence of any commercial or financial relationships that could be construed as a potential conflict of interest.

Publisher's Note: All claims expressed in this article are solely those of the authors and do not necessarily represent those of their affiliated organizations, or those of the publisher, the editors and the reviewers. Any product that may be evaluated in this article, or claim that may be made by its manufacturer, is not guaranteed or endorsed by the publisher.

Copyright $\odot 2021$ Rivas, Liu and Heuvelink. This is an open-access article distributed under the terms of the Creative Commons Attribution License (CC BY). The use, distribution or reproduction in other forums is permitted, provided the original author(s) and the copyright owner(s) are credited and that the original publication in this journal is cited, in accordance with accepted academic practice. No use, distribution or reproduction is permitted which does not comply with these terms. 